This item was submitted to Loughborough's Research Repository by the author.

Items in Figshare are protected by copyright, with all rights reserved, unless otherwise indicated.

\title{
An unexpected stereochemical course of dihydroimidazolium ylide cycloadditions
}

PLEASE CITE THE PUBLISHED VERSION

http://dx.doi.org/10.1002/asia.200900547

\section{PUBLISHER}

(C) Wiley-VCH Verlag GmbH \& Co.

\section{VERSION}

AM (Accepted Manuscript)

\section{PUBLISHER STATEMENT}

This work is made available according to the conditions of the Creative Commons Attribution-NonCommercialNoDerivatives 4.0 International (CC BY-NC-ND 4.0) licence. Full details of this licence are available at: https://creativecommons.org/licenses/by-nc-nd/4.0/

\section{LICENCE}

CC BY-NC-ND 4.0

\section{REPOSITORY RECORD}

Jones, Raymond C.F., Shabana Rafiq, Mark R.J. Elsegood, Vickie McKee, and Martin J. Slater. 2019. "An Unexpected Stereochemical Course of Dihydroimidazolium Ylide Cycloadditions". figshare. https://hdl.handle.net/2134/15711. 


\title{
An Unexpected Stereochemical Course of Dihydroimidazolium Ylide Cycloadditions
}

\author{
Raymond C. F. Jones, ${ }^{*[a]}$ Shabana Rafiq, ${ }^{[a]}$ Mark R. J. Elsegood, ${ }^{[a]}$ Vickie McKee ${ }^{[a]}$ and \\ Martin J. Slater ${ }^{[b]}$
}

Dedicated to the 150th anniversary of Japan-UK diplomatic relations

\begin{abstract}
Chemists continue to seek methods to assemble saturated nitrogen heterocycles to exploit pharmacological potential. ${ }^{[1]}$ We have an ongoing interest in the preparation of pyrrolo[1,2-a]imidazoles by diastereoselective 1,3 -dipolar cycloaddition of 4,5-dihydroimidazolium ylides $\mathbf{1}$, formed in situ from dihydroimidazoles, an alkylating agent, and base, ${ }^{[2]}$ or more recently by carbenoid insertion onto the dihydroimidazole $\mathrm{N}(1)$ lone pair. ${ }^{[3]}$ We have elaborated these primary cycloadducts to produce pyrrolidines, pyrrolizidines, indolizidines, ${ }^{[4]}$ and (by intramolecular cycloaddition) imidazo[1,2-a]indoles which can undergo cascade conversion into pyrrolo[1,2,3de quinoxalines. $^{[5]}$ Cycloaddition of optically active ylides produces optically active pyrrolidines via pyrrolo[1,2-a]imidazoles, exemplified in Scheme 1. ${ }^{[6]}$ 4,5-Dihydroimidazole (2-imidazoline) derivatives display a range of pharmacological properties; pyrrolo[1,2-a]imidazoles have themselves recently been investigated as JNK3 inhibitors. ${ }^{[7]}$

When assembling reduced heterocycles, it is clearly of great importance to be able to predict the stereochemical outcome. In all of the cases reported to date, the dipolarophile is an electron-deficient alkene activated by a carbonyl group, usually an ester, or by a nitrile, that is, by a planar $\mathrm{sp}^{2}$ or a linear sp carbon atom, and the diastereoselectivity shown by the major (and in most cases the only) cycloadduct is consistent with the transition-state model of Figure 1, involving an anti dipole and an endo approach by the dipo-
\end{abstract}

[a] Prof. R. C. F. Jones, S. Rafiq, M. R. J. Elsegood, Prof. V. McKee Department of ChemistryLoughborough University

Loughborough, Leics. LE11 3TU (UK)

Fax: (+44)1509-222557

E-mail: r.c.f.jones@lboro.ac.uk

[b] M. J. Slater

GlaxoSmithKline Research \& Development Ltd Medicines Research Centre

Gunnels Wood Road, Stevenage, Herts. SG1 2NY (UK)

Supporting information for this article is available on the WWW under http://dx.doi.org/10.1002/asia.200900547.

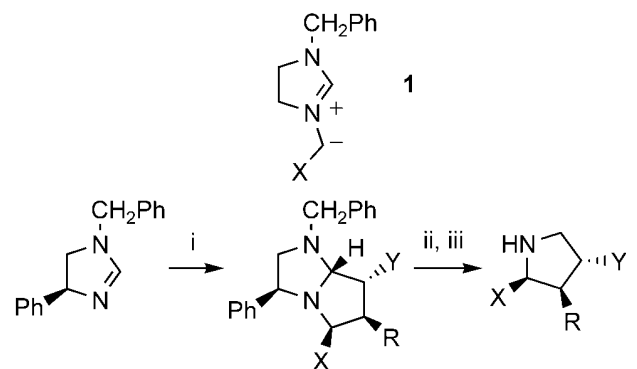

Scheme 1. Dihydroimidazolium ylides in pyrrolidine synthesis. Reagents: i) $\mathrm{BrCH}_{2} \mathrm{X}, \mathrm{RCH}=\mathrm{CHY}, \mathrm{DBU}$; ii) $\mathrm{NaBH}_{3} \mathrm{CN}, \mathrm{H}^{+}$; iii) $\mathrm{Pd}(\mathrm{OH})_{2}, \mathrm{H}_{2}$.

larophile..$^{[2,8]}$ With a view to developing a traceless dipolarophile activation, ${ }^{[9]}$ we have investigated potentially removable sulfur-containing activating groups, principally sulfone. We report herein the results of cycloadditions using a range of vinyl sulfones, the unexpected stereochemical outcomes observed, and a new secondary re-

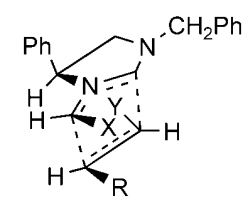

Figure 1. Transition-state model for dihydroimidazolium ylide endo cycloaddition (Scheme 1) where $\mathrm{Y}=$ ester, ketone, nitrile, i.e., $\mathrm{sp}^{2}$ or $\mathrm{sp}$ activating group. action of the cycloadducts.

Initial studies employed 1-

benzyl-4,5-dihydroimidazole $\mathbf{2}$ a, using our previously reported one-pot protocol. ${ }^{[2]}$ Thus the dihydroimidazole, alkylating agent, and dipolarophile ( $3 \mathrm{~mol}$ equiv of dipolarophile) were mixed in THF at reflux and DBU was added dropwise over $4 \mathrm{~h}$. Using tert-butyl bromoacetate and phenyl vinyl sulfone, cycloadduct 3 a was isolated ( $45 \%$ ) after column chromatography and recrystallization (Scheme 2). In contrast to our previous reports with carbonyl- and nitrile-activated dipolarophiles, pyrrolo[1,2-a]imidazole 3 a results from the unexpected exo approach of the dipolarophile to the dipole. This was indicated by a nuclear Overhauser effect (n.O.e.) inves- 


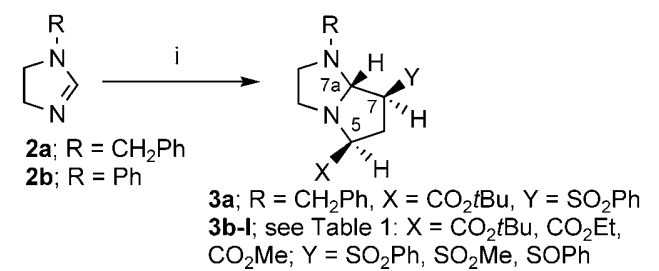

Scheme 2. Exo dipolar cycloadditions of achiral dihydroimidazoles 2 with sulfur-activated dipolarophiles. Reagents: i) $\mathrm{BrCH}_{2} \mathrm{X}, \mathrm{CH}_{2}=\mathrm{CHY}$, DBU.

tigation, which demonstrated, for example, enhancement at $\mathrm{C}(5)-\mathrm{H}$ on irradiation at $\mathrm{C}(7)-\mathrm{H}$, that is, a cis relationship between $\mathrm{C}(5)$ and $\mathrm{C}(7)$ substituents, and was confirmed by an X-ray crystal structure determination (Figure 2). We speculate that the extra steric requirement of the tetrahedral sulfone moiety may overcome any secondary orbital interactions that favor an endo approach for $\mathrm{sp}^{2}$ activating groups.

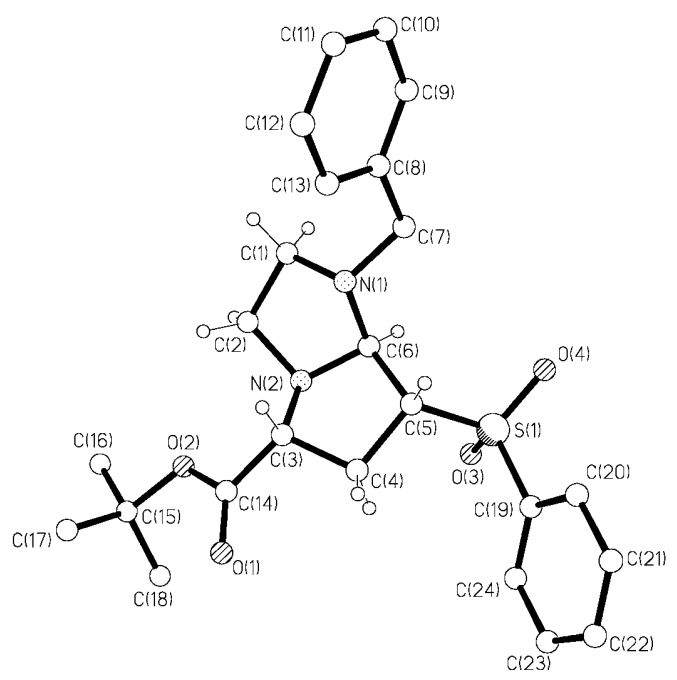

Figure 2. X-ray crystal structure of $\mathbf{3 a}$ (enantiomer, crystallographic numbering).

Further examples of the cycloadducts of $\mathbf{2 a}$ with phenyl vinyl sulfone were added using ethyl bromoacetate, methyl bromoacetate, and bromoacetonitrile to afford pyrroloimidazoles $\mathbf{3 b} \mathbf{b}-\mathbf{d}$, and these results are summarized in Table 1.

Table 1. Exo dipolar cycloadditions of achiral dihydroimidazoles 2 with sulfur-activated dipolarophiles.

\begin{tabular}{llll}
\hline Dipolarophile & $\begin{array}{l}\text { Alkylating } \\
\text { agent }\end{array}$ & $\begin{array}{l}\text { Adducts 3 from di- } \\
\text { hydroimidazole 2a } \\
\left(\mathrm{R}=\mathrm{CH}_{2} \mathrm{Ph}\right)(\text { Yield })\end{array}$ & $\begin{array}{l}\text { Adducts 3 from di- } \\
\text { hydroimidazole 2 b } \\
(\mathrm{R}=\mathrm{Ph}) \text { (Yield) }\end{array}$ \\
\hline $\mathrm{CH}_{2}=\mathrm{CHSO}_{2} \mathrm{Ph}$ & $\mathrm{BrCH}_{2} \mathrm{CO}_{2} t \mathrm{Bu}$ & $\mathbf{3 a}(45 \%)$ & $\mathbf{3 h}(55 \%)$ \\
$\mathrm{CH}_{2}=\mathrm{CHSO}_{2} \mathrm{Ph}$ & $\mathrm{BrCH}_{2} \mathrm{CO}_{2} \mathrm{Et}$ & $\mathbf{3 b}(18 \%)$ & $\mathbf{3 i}(29 \%)$ \\
$\mathrm{CH}_{2}=\mathrm{CHSO}_{2} \mathrm{Ph}$ & $\mathrm{BrCH}_{2} \mathrm{CO}_{2} \mathrm{Me}$ & $\mathbf{3 c}(12 \%)$ & $\mathbf{3 j}(25 \%)$ \\
$\mathrm{CH}_{2}=\mathrm{CHSO}_{2} \mathrm{Ph}$ & $\mathrm{BrCH}_{2} \mathrm{CN}_{2}$ & $\mathbf{3 d}(25 \%)$ & \\
$\mathrm{CH}_{2}=\mathrm{CHSO}_{2} \mathrm{Me}$ & $\mathrm{BrCH}_{2} \mathrm{CO}_{2} \mathrm{Bu}$ & $\mathbf{3 e}(37 \%)$ & $\mathbf{3 k}(57 \%)$ \\
$\mathrm{CH}_{2}=\mathrm{CHSO}_{2} \mathrm{Me}$ & $\mathrm{BrCH}_{2} \mathrm{CO}_{2} \mathrm{Me}$ & $\mathbf{3 f}(10 \%)$ & \\
$\mathrm{CH}_{2}=\mathrm{CHSOPh}$ & $\mathrm{BrCH}_{2} \mathrm{CO}_{2} t \mathrm{Bu}$ & $\mathbf{3 g}(26 \%)$ & $\mathbf{3 l}(22 \%)$ \\
\hline
\end{tabular}

The dipolarophile was replaced by methyl vinyl sulfone to afford cycloadducts $\mathbf{3 e}$,f using tert-butyl and methyl bromoacetate as alkylating agents, respectively, and by phenyl vinyl sulfoxide to afford $\mathbf{3} \mathbf{g}$ using tert-butyl bromoacetate as an alkylation partner. The dihydroimidazole component could be replaced by 1-phenyl-4,5-dihydroimidazole $\mathbf{2 b}$ to afford cycloadducts $\mathbf{3 h}-\mathbf{j}$ of phenyl vinyl sulfone using tertbutyl, ethyl, and methyl bromoacetate, respectively, and $\mathbf{3 k} \mathbf{l}$ with methyl vinyl sulfone and phenyl vinyl sulfoxide, respectively, using tert-butyl bromoacetate. Although the yields were moderate, no other cycloadducts (isomers) were isolated.

The adducts $\mathbf{3 a}-\mathbf{f}, \mathbf{h}-\mathbf{I}$ shown in Table 1 all displayed the same relative stereochemistry as seen in $\mathbf{3 a}$, that is, exo cycloaddition (Figure 3). ${ }^{[10]}$ This

finding was supported in each case by extensive n.O.e. studies. For example, $N$-phenyl adduct 3h showed enhancement of $\mathrm{C}(5)-\mathrm{H}$ as well as one of $\mathrm{C}(6)$ $\mathrm{H}$ on irradiation of $\mathrm{C}(7)-\mathrm{H}$, and irradiation of $\mathrm{C}(5)-\mathrm{H}$ showed the reciprocal enhancements; no enhancement of bridgehead proton $\mathrm{C}(7 \mathrm{a})-\mathrm{H}$ was observed. Further X-ray crystal structures were obtained for $3 \mathbf{e}$ (Figure 4) and the $N$-phenyl derivative $\mathbf{3 k}$ (Figure 5). In the latter case, two independent molecules were observed in the unit cell, both having the same relative stereochemistry but differing in exact conformation, and just one is illustrated in Figure 5. The sulfoxide cycloadduct $\mathbf{3 g}$ was obtained as an inseparable 1:1 stereoisomer mixture which, based on all the other results in Table 1, we tentatively assume to be due to the sulfoxide stereocenter; the isolation of $\mathbf{3 1}$ as one (exo) diastereomer is, we assume, due to a selective crystallization.

Interestingly, in the cases of the methyl bromoacetate cycloadducts $\mathbf{3 c}, \mathbf{f}, \mathbf{j}$, second products were isolated $(15,5$, and

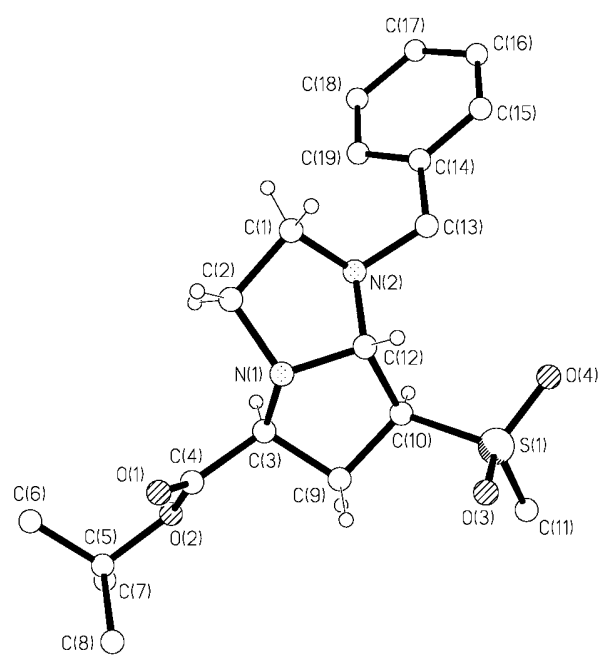

Figure 4. X-ray crystal structure of $\mathbf{3 e}$ (crystallographic numbering). 


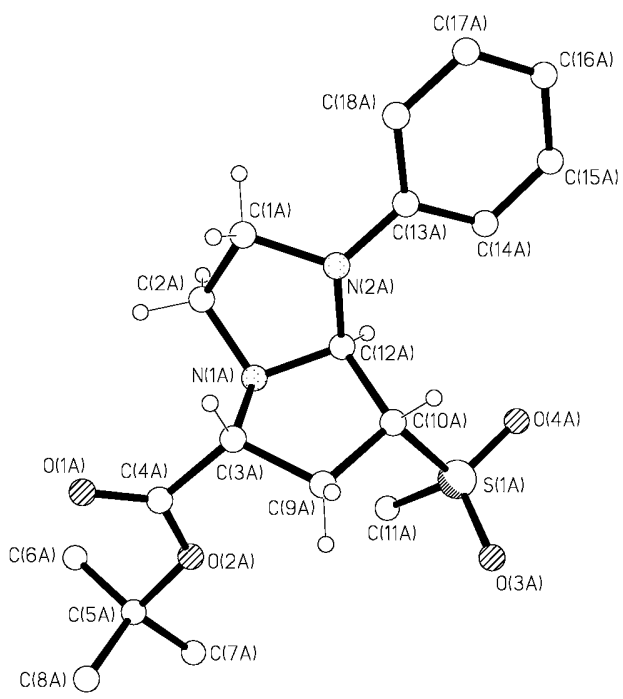

Figure 5. X-ray crystal structure of $\mathbf{3 k}$ (enantiomer, crystallographic numbering, one of two similar molecules in the asymmetric unit).

$15 \%$, respectively) displaying an extra methoxy signal in their ${ }^{1} \mathrm{H}$ NMR spectra, which were shown to be the eightmembered ring compounds $\mathbf{4 a - c}$, respectively. The structure of $\mathbf{4 a}$ was confirmed by an X-ray crystal structure determination (Figure 6). We propose that $\mathbf{4 a - c}$ arise from alkylation of the bridgehead nitrogen atom of primary cycloadducts $\mathbf{3 c}, \mathbf{f}, \mathbf{j}$ followed by Hoffman-type $\beta$-elimination (Scheme 3) to give the cyclic $(E)$-alkene.

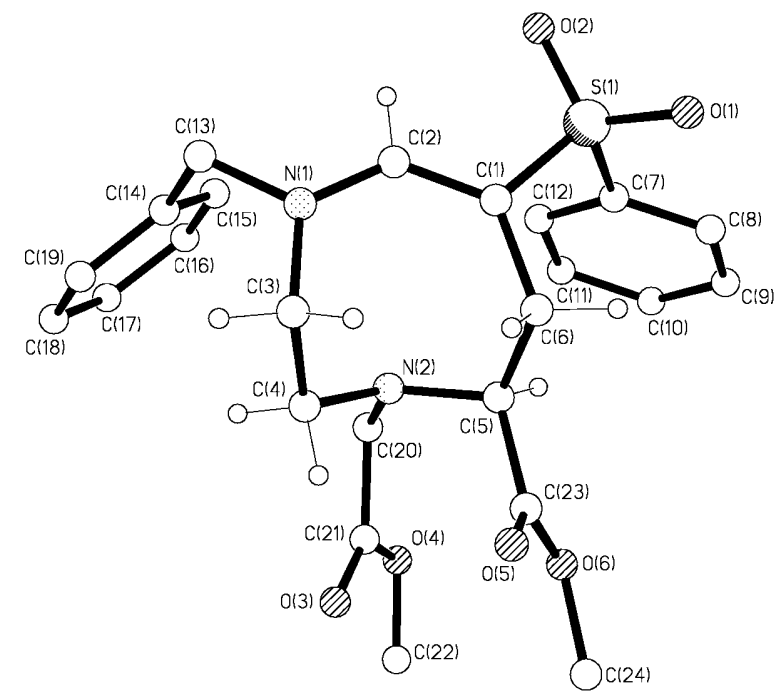

Figure 6. X-ray crystal structure of $\mathbf{4 a}$ (crystallographic numbering).

With all the achiral dihydroimidazole sulfone and sulfoxide-substituted adducts 3 showing the unexpected exo cycloaddition mode, we investigated reactions of the chiral 4phenyl-4,5-dihydroimidazoles $\mathbf{5}$ a-c. Using first the 1-benzyldihydromidazole $\mathbf{5} \mathbf{a}$ and phenyl vinyl sulfone, pyrroloimidazoles $\mathbf{6 a}$ a-c were isolated using tert-butyl, ethyl, and methyl

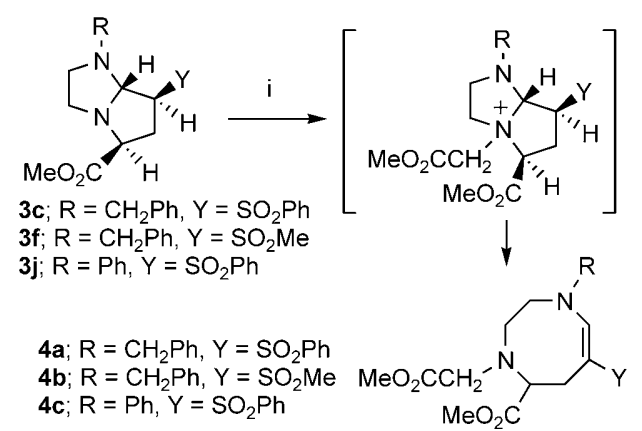

Scheme 3. Secondary transformation of cycloadducts $\mathbf{3 c}, \mathbf{f}, \mathbf{j}$. Reagents: i) $\mathrm{BrCH}_{2} \mathrm{CO}_{2} \mathrm{Me}$.

bromoacetates as alkylating agent (Scheme 4, Table 2). We were surprised to find that these cycloadducts were now in the endo series. Thus 6a showed n.O.e. enhancements at

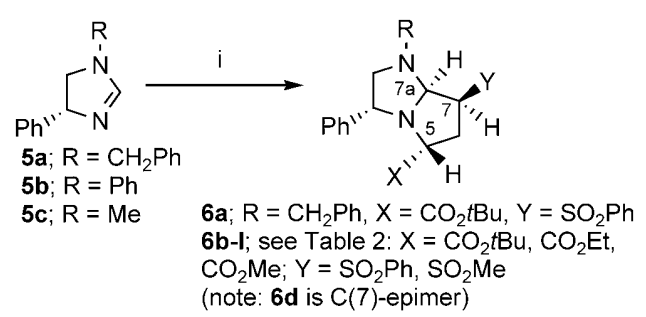

Scheme 4. Endo dipolar cycloadditions of chiral dihydroimidazoles 5 with sulfur-activated dipolarophiles. Reagents: i) $\mathrm{BrCH}_{2} \mathrm{X}, \mathrm{CH}_{2}=\mathrm{CHY}, \mathrm{DBU}$.

Table 2. Endo dipolar cycloadditions of chiral dihydroimidazoles 5 with sulfur-activated dipolarophiles.

\begin{tabular}{lllll}
\hline $\begin{array}{l}\text { Dipolarophile } \\
\mathrm{CH}_{2}=\mathrm{CHY} ;\end{array}$ & $\begin{array}{l}\text { Alkylating } \\
\text { agent }\end{array}$ & $\begin{array}{l}\text { Adducts 6 } \\
\text { from 5a } \\
\left(\mathrm{RrCH}=\mathrm{CH}_{2} \mathrm{Ph}\right)\end{array}$ & $\begin{array}{l}\text { Adducts 6 } \\
\text { from 5b } \\
(\mathrm{R}=\mathrm{Ph})\end{array}$ & $\begin{array}{l}\text { Adducts 6 } \\
\text { from 5c } \\
(\mathrm{R}=\mathrm{Me})\end{array}$ \\
& $\mathrm{X}=$ & $($ Yield $)$ & $($ Yield $)$ & $($ Yield) \\
\hline $\mathrm{SO}_{2} \mathrm{Ph}$ & $\mathrm{CO}_{2} t \mathrm{Bu}$ & $\mathbf{6 a}(28 \%)$ & $\mathbf{6 f}(19 \%)$ & $\mathbf{6 h}(22 \%)$ \\
$\mathrm{SO}_{2} \mathrm{Ph}$ & $\mathrm{CO}_{2} \mathrm{Et}$ & $\mathbf{6 b}(25 \%)$ & & $\mathbf{6 i}(16 \%)$ \\
$\mathrm{SO}_{2} \mathrm{Ph}$ & $\mathrm{CO}_{2} \mathrm{Me}$ & $\mathbf{6 c}(19 \%)$ & $\mathbf{6 g}(25 \%)$ & $\mathbf{6 j}(10 \%)$ \\
$\mathrm{SO}_{2} \mathrm{Me}$ & $\mathrm{CO}_{2} t \mathrm{Bu}$ & $\mathbf{6 d}(25 \%)^{[\mathrm{a}]}$ & & $\mathbf{6 k}(19 \%)$ \\
$\mathrm{SO}_{2} \mathrm{Me}$ & $\mathrm{CO}_{2} \mathrm{Me}$ & $\mathbf{6 e}(12 \%)$ & & $\mathbf{6 I}(12 \%)$
\end{tabular}

[a] 6d is exo adduct, i.e., epimer at C(7).

$\mathrm{C}(7)-\mathrm{H}$, but not at $\mathrm{C}(5)-\mathrm{H}$, on irradiation of bridgehead $\mathrm{C}(7 \mathrm{a})-\mathrm{H}$. Irradiation of $\mathrm{C}(7)-\mathrm{H}$ produced enhancement of $\mathrm{C}(7 \mathrm{a})-\mathrm{H}$ and one proton at $\mathrm{C}(6)$, but again not of $\mathrm{C}(5)-\mathrm{H}$. Finally, irradiation of $\mathrm{C}(5)-\mathrm{H}$ showed enhancement of the other proton at $\mathrm{C}(6)$, as well as $\mathrm{C}(3)-\mathrm{H}$. This demonstrates the trans relationship of the $\mathrm{C}(5)$ and $\mathrm{C}(7)$ substituents, also the cis relationships of $\mathrm{C}(3)$ and $\mathrm{C}(5)$ substituents, and of $\mathrm{C}(7)-\mathrm{H}$ with $\mathrm{C}(7 \mathrm{a})-\mathrm{H}$. The relative stereochemistries of $\mathbf{6} \mathbf{a}, \mathbf{c}$ were each confirmed by X-ray crystal structure determination (Figures 7 and 8, respectively).

Further examples 6d,e of pyrrolo[1,2- $a$ ] imidazoles from chiral dihydroimidazole $\mathbf{5 a}$ were obtained by using methyl 


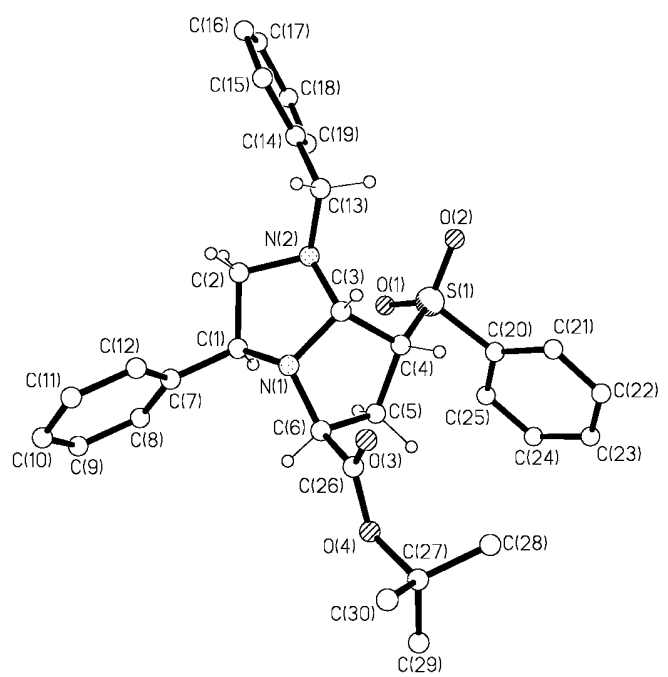

Figure 7. X-ray crystal structure of $\mathbf{6 a}$ (enantiomer, crystallographic numbering).

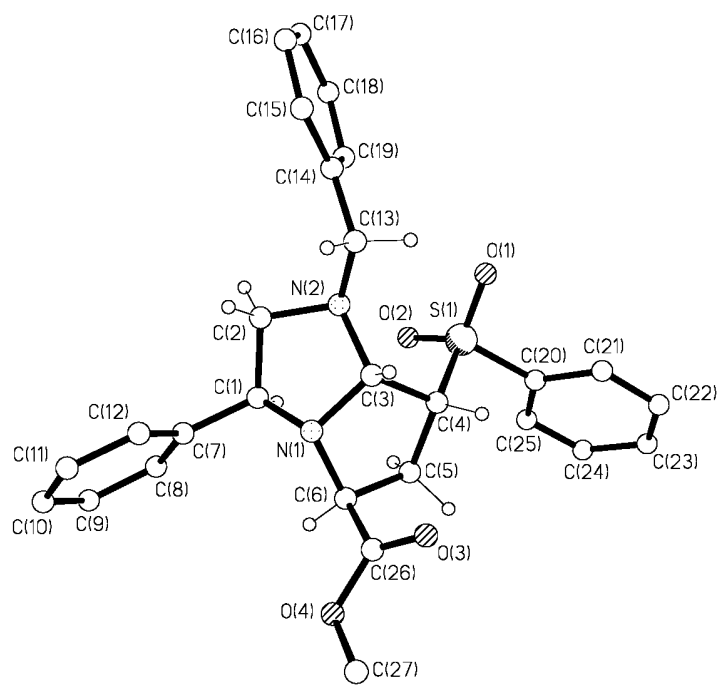

Figure 8. X-ray crystal structure of $\mathbf{6 c}$ (enantiomer, crystallographic numbering).

vinyl sulfone and tert-butyl or methyl bromoacetate. Replacing the 4-phenyldihydroimidazole by the $N$-phenyl derivative $5 \mathbf{b}$ led to adducts $\mathbf{6} \mathbf{f}, \mathbf{g}$ from phenyl vinyl sulfone with tert-butyl and ethyl bromoacetate, respectively. Finally, $N$ methyldihydroimidazole $5 \mathbf{c}$ gave cycloadducts $\mathbf{6 h}-\mathbf{j}$ using phenyl vinyl sulfone with tert-butyl, ethyl, and methyl bromoacetate, and $\mathbf{6 k , \mathbf { l }}$ from methyl vinyl sulfone with tertbutyl and methyl bromoacetate, respectively. Yields of these cycloadducts are unoptimized, but no other cycloadducts (isomers) were isolated.

In all cases except one, endo adducts were the only observed cycloaddition products. The exception was $\mathbf{6 d}$, where an exo relative configuration was revealed by an X-ray crystal structure determination (not illustrated). We have no ra- tionale for this exception. No secondary eight-membered ring products were observed, possibly because the 3-phenyl substituent in the primary adducts $\mathbf{6}$ restricted access to the bridgehead nitrogen atom by a further alkylating agent.

We have therefore observed an unexpected switch of cycloaddition mode from endo to exo for sulfone-activated dipolarophiles with achiral dihydroimidazolium ylides that may be related to the extra steric requirement of tetrahedral sulfur activating groups. This did not occur for chiral dihydroimidazoles, with just one exception amongst the examples reported. The cycloaddition mode should not affect the search for traceless activation via post-cycloaddition $\mathrm{C}-\mathrm{S}$ bond cleavage, nor functionalization $\alpha$ to the sulfone group, which should proceed via a planar carbanion. ${ }^{[1]}$ Work in these directions is ongoing.

\section{Experimental Section}

General procedure for dipolar cycloadditions, exemplified for 1-benzyl-5tert-butoxycarbonyl-7-phenylsulfonylhexahydropyrrolo[1,2-a]imidazole $(\mathbf{3 a}$; data for other compounds are provided in the Supporting Information): 1-Benzyl-4,5-dihydroimidazole $2 \mathrm{a}(1.02 \mathrm{~g}, 6.38 \mathrm{mmol})$, tert-butyl bromoacetate $(1.00 \mathrm{~mL}, 6.38 \mathrm{mmol})$, and phenyl vinyl sulfone $(3.29 \mathrm{~g}$, $19.14 \mathrm{mmol})$ in freshly distilled THF $(30 \mathrm{~mL})$ were placed in a threenecked round-bottom flask and heated to reflux under nitrogen. DBU $(10.98 \mathrm{~mL}, 6.38 \mathrm{mmol})$ was then added to the reaction mixture using a syringe pump over $4 \mathrm{~h}$, and the reaction was heated under reflux for a further $2 \mathrm{~h}$, at which point the reaction mixture was cooled to room temperature and evaporated under reduced pressure. The residue was treated with water $(30 \mathrm{~mL})$, extracted with chloroform $(3 \times 30 \mathrm{~mL})$, and the combined organic layers were dried $\left(\mathrm{Na}_{2} \mathrm{SO}_{4}\right)$, filtered, and evaporated under reduced pressure to a dark viscous oil. The product was purified by column chromatography on silica gel (Merck Kieselgel 60H), eluting with hexane/ethyl acetate $(7: 3 \mathrm{v} / \mathrm{v})$ to afford a white solid. The solid still contained some phenyl vinyl sulfone, however triturating with a minimum amount of propan-2-ol gave the title compound as a white solid $(1.21 \mathrm{~g}, 45 \%)$; m.p. $145.5-146.7^{\circ} \mathrm{C}$ (found: $\mathrm{C} 65.13, \mathrm{H} 6.82, \mathrm{~N} 6.42, \mathrm{MH}^{+}$ 443.201; $\mathrm{C}_{24} \mathrm{H}_{30} \mathrm{~N}_{2} \mathrm{O}_{4} \mathrm{~S}$ requires $\mathrm{C} 65.13, \mathrm{H} 6.83, \mathrm{~N} 6.33, \mathrm{MH}^{+}$443.200); $\tilde{v}_{\max }($ film $)=1737(\mathrm{C}=\mathrm{O}), 1306(\mathrm{~S}=\mathrm{O}), 1147 \mathrm{~cm}^{-1}(\mathrm{~S}=\mathrm{O}) ;{ }^{1} \mathrm{H} \quad \mathrm{NMR}$ $\left(400 \mathrm{MHz} ; \quad\left(\mathrm{CD}_{3}\right)_{2} \mathrm{SO}\right): 1.40 \quad\left(9 \mathrm{H}, \quad \mathrm{s}, \quad \mathrm{C}\left(\mathrm{CH}_{3}\right)_{3}\right), 2.21-2.33 \quad(3 \mathrm{H}, \quad \mathrm{m}$, $\mathrm{NCHHCH}_{2} \mathrm{~N}$ and $\left.\mathrm{CHCH}_{2}\right), 2.70-2.75\left(1 \mathrm{H}, \mathrm{m}, \mathrm{NCH}_{2} \mathrm{CHHN}\right), 2.78-2.82$ $\left(1 \mathrm{H}, \mathrm{m}, \mathrm{NCHHCH}_{2} \mathrm{~N}\right), 2.96(1 \mathrm{H}, \mathrm{d}, \mathrm{J}=13.0 \mathrm{~Hz}, \mathrm{PhCH}), 2.99-3.02$ $\left(1 \mathrm{H}, \mathrm{m}, \mathrm{NCH}_{2} \mathrm{CH} H \mathrm{~N}\right), 3.44\left(1 \mathrm{H}, \mathrm{dd}, \mathrm{J}=6.8\right.$ and $\left.9.9 \mathrm{~Hz}, \mathrm{CHCH}_{2}\right), 3.61$ $(1 \mathrm{H}, \mathrm{d}, \mathrm{J}=13.0 \mathrm{~Hz}, \mathrm{PhCH} H), 3.98-4.04\left(2 \mathrm{H}, \mathrm{m}, \mathrm{CHSO}_{2}\right.$ and $\left.\mathrm{C}(7 \mathrm{a})-\mathrm{H}\right)$ and 7.18-8.00 ppm (10H, m, Ar-H); ${ }^{13} \mathrm{C}$ NMR $\left(100 \mathrm{MHz} ;\left(\mathrm{CD}_{3}\right)_{2} \mathrm{SO}\right): 27.6$ $\left(\mathrm{C}\left(\mathrm{CH}_{3}\right)_{3}\right), 30.7\left(\mathrm{CHCH}_{2}\right), 50.8,51.2\left(2 \times \mathrm{NCH}_{2}\right), 55.0\left(\mathrm{PhCH}_{2}\right), 65.8$

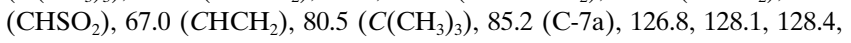
128.5, 129.6, $136.3(6 \times \mathrm{Ar}-\mathrm{CH}), 137.8,138.7(2 \mathrm{x} \mathrm{Ar}-\mathrm{C}), 170.3 \mathrm{ppm}(\mathrm{C}=$ O); $m / z 443\left[\mathrm{MH}^{+}\right], 387,274,91$

Crystal data were collected on a Bruker SMART 1000 CCD diffractometer using narrow slice $0.3^{\circ} \omega$ scans for $\mathbf{3 e}, \mathbf{3} \mathbf{k}$, and $\mathbf{4} \mathbf{a}^{[12]}$ (Bruker APEX 2 for $3 \mathbf{a}, \mathbf{6} \mathbf{a}, \mathbf{6 c}$, and $\mathbf{6 d}$ ). Data for $3 \mathbf{a}$ were collected at Daresbury Laboratory SRS Station 9.8 using silicon 111 monochromated X-radiation. ${ }^{[12]}$ Data were corrected for $\mathrm{Lp}$ effects and for absorption, based on repeated and symmetry equivalent reflections, and solved by direct methods. ${ }^{[13,14]}$ Structures were refined by full matrix least squares on $F^{2} \cdot{ }^{[13,14]} \mathrm{H}$ atoms were included in a riding model. Hydrogen atom $U_{\text {iso }}$ values were constrained to be $120 \%$ of that of the carrier atom except for methyl- $\mathrm{H}$ $(150 \%)$. Crystallographic data are provided in the Supporting Information; CCDC 747655, CCDC 747656, CCDC 747657, CCDC 747658, CCDC 747659, CCDC 747660, CCDC 747661 contain the supplementary crystallographic data for this paper, for $3 a, 3 e, 3 \mathbf{k}, 4 \mathbf{a}, 6 \mathbf{a}, 6 \mathbf{b}, 6 \mathbf{c}, \mathbf{6 d}$. These data can be obtained free of charge from The Cambridge Crystallographic Data Centre via www.ccdc.cam.ac.uk/data_request/cif. 


\section{Acknowledgements}

We thank EPSRC and GlaxoSmithKline for an Industrial CASE Award (S.R.), the EPSRC Mass Spectrometry Service Centre (Swansea) for high-resolution MS data., the STFC for beam time at Daresbury Laboratory and Dr. J. E. Warren for scientific support on Station 9.8.

Keywords: diastereoselectivity • dipolar cycloaddition • pyrroloimidazoles $\cdot$ sulfones $\cdot$ ylides

[1] See, for example: G. Pandey, P. Banerjee, S. R. Gadre, Chem. Rev. 2006, 106, 4484-4517.

[2] R. C. F. Jones, K. J. Howard, J. R. Nichols, J. S. Snaith, J. Chem. Soc. Perkin Trans. 1 1998, 2061-2072.

[3] R. C. F. Jones, J. N. Iley, M. Sanchis-Amat, X. Zhang, M. R. J. Elsegood, Tetrahedron Lett. 2009, 50, 3577-3579.

[4] R. C. F. Jones, K. J. Howard, J. S. Snaith, Tetrahedron Lett. 1996, 37, 1711-1714; R. C. F. Jones, K. J. Howard, J. S. Snaith, Tetrahedron Lett. 1997, 38, 1647-1650.

[5] P. M. J. Lory, R. C. F. Jones, J. N. Iley, S. J. Coles, M. B. Hursthouse, Org. Biomol. Chem. 2006, 4, 3155-3165.

[6] R. C. F. Jones, K. J. Howard, J. S. Snaith, Tetrahedron Lett. 1996, 37, 1707-1710.

[7] P. P. Graczyk, A. Khan, G. S. Bhatia, V. Palmer, D. Medland, H. Numata, H. Oinuma, J. Catchick, A. Dunne, M. Ellis, C. Smales, J.
Whitfield, S. J. Neame, B. Shah, D. Wilton, L. Morgan, T. Patel, R. Chung, H. Desmond, J. M. Staddon, N. Satob, A. Inoueb, Bioorg. Med. Chem. Lett. 2005, 15, 4666-4670.

[8] $C f$. for example: H. Ardill, M. J. R. Dorrity, R. Grigg, M.-S. Leonling, J. F. Malone, V. Sridharan, S. Thianpatanagul, Tetrahedron 1990, 46, 6433-6448; H. Ardill, X. L. R. Fontaine, R. Grigg, D. Henderson, J. Montgomery, V. Sridharan, S. Surendrakumar, Tetrahedron 1990, 46, 6449-6466, and references therein.

[9] Unactivated dipolarophiles usually require intramolecular cycloaddition, for example: A. J. M. Burrell, I. Coldham, L. Watson, N. Oram, C. D. Pilgram, N. G. Martin, J. Org. Chem. 2009, 74, 2290-2300; I. Coldham, R. Hufton, Chem. Rev. 2005, 105, 2765-2810; V. Nair, T. D. Suja, Tetrahedron 2007, 63, 12247-12275.

[10] For an example of sulfone activation giving an endo/exo mixture, see: A. J. M. Burrell, I. Coldham, N. Oram, Org. Lett. 2009, 11 $1515-1518$.

[11] See, for example: J. P. Clayden, N. Greeves, S. G. Warren, P. D. Wothers, Organic Chemistry, Oxford University Press, Oxford, 2001, p. 1252.

[12] SMART (2001), SAINT (2001\&2008), and APEX 2 (2008) software for CCD diffractometers. Bruker AXS Inc., Madison, USA.

[13] Sheldrick, G. M., SHELXTL user manual, version 6.10. Bruker AXS Inc., Madison, WI, USA, (2000).

[14] G. M. Sheldrick, Acta Crystallogr. Sect. A 2008, 64, 112-122.

Received: October 12, 2009 Published online: $\mathbf{\square}$ an, 2009 


\section{COMMUNICATION}

Cycloaddition

R. C. F. Jones, * S. Rafiq,

M. R. J. Elsegood, V. McKee,

M. J. Slater

III-III

An Unexpected Stereochemical Course of Dihydroimidazolium Ylide Cycloadditions

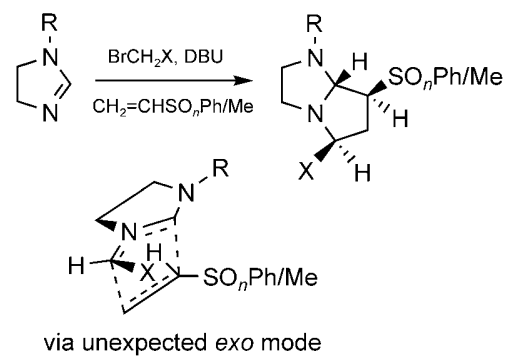

via unexpected exo mode
Turning the tables: We have observed an unexpected switch of cycloaddition mode from endo to exo for sulfoneactivated dipolarophiles with achiral dihydroimidazolium ylides to produce pyrrolo[1,2-a]imidazoles, that may be related to the extra steric requirement of tetrahedral sulfur activating groups. This did not occur for chiral dihydroimidazoles, with just one exception amongst the examples reported. 